\title{
The Difference Between the Physical Properties of Petrol ANd Alkylate Petrol AND ImPaCt ON THE EXHAUST GAS OF A TWO-STROKE ENGINE
}

\author{
Risto Ilves $^{\mathrm{a}}$, Arne Küüt ${ }^{\mathrm{a}}$, Gints Birzietis ${ }^{\mathrm{b}}$, Vilnis Pirs ${ }^{\mathrm{b}}$, Andrey Vlasov ${ }^{\mathrm{a}}$, Jüri Olt ${ }^{\mathrm{a}}$ \\ ${ }^{a}$ Institute of Technology, Estonian University of Life Sciences, Kreutzwaldi 56, Tartu, EE51014, Estonia \\ ${ }^{b}$ Motor Vehicle Institute, Faculty of Engineering, Latvia University of Agriculture, 5 J. Cakstes boulv., \\ Jelgava, LV-3001, Latvia.
}

\begin{abstract}
The use of a two-stroke engine as the power unit on different hand tools is a widespread tendency. In case of the particular hand tools, it is crucial to keep the exhaust gas emission of the engine as low as possible. To reduce the exhaust gas emission of a two-stroke engine, alkylate petrol has been worked out. According to manufacturer's data, using alkylate petrol in a two-stroke engine improves the combustion of the air-fuel mixture, thus, the proportion of dangerous compounds in the engine exhaust gas also decreases. However, it is not exactly clear how much the proportion of dangerous compounds, e.g. carbon monoxide, in the exhaust gas decreases. The aim of the given article is to study the exhaust gas emission during the combustion of alkylate petrol and outline the proportion of dangerous compounds at different loads of a two-stroke engine. The results indicate that when alkylate petrol is used, the proportion of carbon monoxide in the exhaust gas increases.
\end{abstract}

Keywords: two stroke engine; gasoline; alkylate petrol; exhaust gas emission; carbon monoxide; fuel properties; 1,3 butadiene
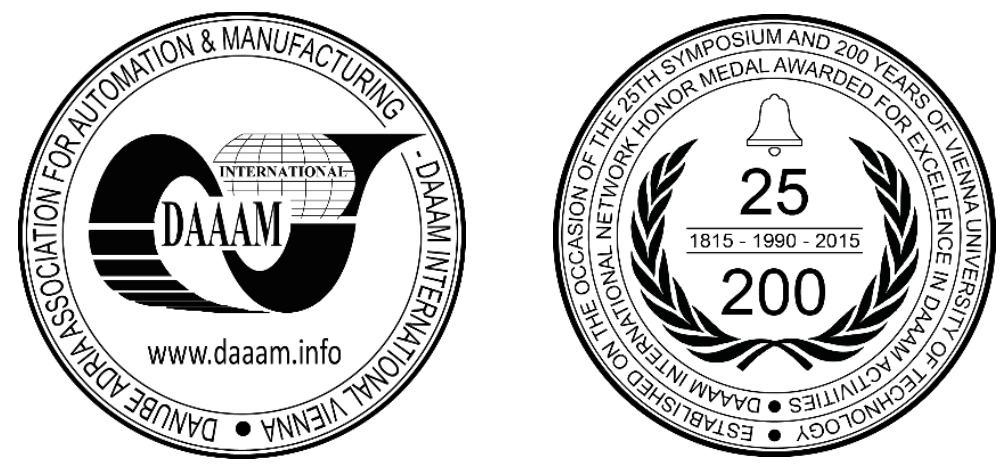

This Publication has to be referred as: Ilves, R[isto]; Kuut, A[rne]; Birzietis, G[ints]; Pirs, V[ilnis]; Vlasov, A[ndrey] $\&$ Olt, J[ueri] (2016). The Difference Between the Physical Properties of Petrol and Alkylate Petrol and Impact on the Exhaust Gas of a Two-Stroke Engine, Proceedings of the 26th DAAAM International Symposium, pp.0562-0569, B. Katalinic (Ed.), Published by DAAAM International, ISBN 978-3-902734-07-5, ISSN 1726-9679, Vienna, Austria DOI: $10.2507 / 26$ th.daaam.proceedings.077 


\section{Introduction}

Two-stroke engines are mostly used on hand tools due to the simplicity of those tools' construction. The fuels used in two-stroke engines are fuel blends, mostly consisting of $98 \%$ regular petrol and $2 \%$ two-stroke engine oil. When operating hand tools, people are subject to health risk as the engine exhaust gas might affect their health, especially when the hand tools are operated over a longer period of time. Therefore, it is important to keep the engine exhaust gas emission during the use of hand tools as low as possible. There are several dangerous compounds in the engine exhaust gas that affect human health. In general, the dangerous compounds in the exhaust gas can be divided into four, i.e. $\mathrm{CO}$, $\mathrm{CO} 2$, NOx, and HC. Carbon monoxide binds to hemoglobin in the human organism, which in turn hinders the transport and use of oxygen in the body. Furthermore, carbon dioxide influences the central nervous system and might cause anesthesia [1]. Nitrogen dioxide causes the irritation of bronchial tubes, and when nitrogen oxides react with hydrocarbons, it results in ground-level ozone that damages the lungs and irritates bronchial tubes [2]. In addition, the impact of the abovementioned exhaust gas compounds on human health is discussed in Fridell et al., 2014, Coburn et al., 2011, Winebrake et al. 2011, etc $[3,4,5]$. Therefore, it is very important to keep the exhaust gas emission of an engine running in close proximity of a human as low as possible.

There are several possibilities to reduce the exhaust gas emission of a two-stroke engine. One of these would be the use of biofuels during which the exhaust gas emission generally reduces $[6,7,8,9,10,11]$. Another option would be using alkylate petrol. Alkylate petrol is a special fuel for use in hand tools that has a low level of alkanes, oxygen and aromatic compounds. The chemical properties of alkylate fuels are more precisely described in Zardini et al., 2014 [12]. According to the data of alkylate petrol's manufacturers, the combustion of alkylate petrol is more effective than, for example, the combustion of the blend of regular petrol and two-stroke engine oil. Therefore, when alkylate petrol is used in a two-stroke engine, the exhaust gas emission decreases. The use of alkylate petrol in two and four-stroke engines has been researched in the world. For instance, Zardini et al. 2014 studies the use of alkylate petrol in two and four-stroke scooter engines [12]. The results indicate that in case of cold and warm engine, the proportions of CO, HC, and NOx reduce in the exhaust gas, whereas the proportion of $\mathrm{CO} 2$ increases. However, the engines of scooters used in the particular test are equipped with a catalyst that reduces the amount of dangerous compounds in the exhaust gas significantly [12]. Therefore, the data in this test do not describe the composition of exhaust gas coming into existence during the combustion of alkylate petrol directly. However, hand tools do not have a catalyst in the exhaust pipes, which would reduce the amount of dangerous compounds in the exhaust gas. For that reason, the exhaust gas emission of two-stroke engines without catalysts might significantly differ from the exhaust gas of engines equipped with one. The impact of alkylate petrol and blends of alkylate petrol and oil produced specifically for two-stroke engines on the exhaust gas of two-stroke engines has been studied as well [13]. In these cases, the difference between fuels lies in the fact that in the alkylate petrol produced specifically for two-stroke engines, the lubrication additive is selected and added by the manufacturer company. Alander et al. (2005) states that in comparison to the use of regular petrol, the proportions of, for example, $\mathrm{CO}$ and $\mathrm{HC}$ in the exhaust gas decrease when alkylate petrol for a two-stroke engine is used [13]. Magnusson et al. (2000, 2002) draws the conclusion that the exhaust gas emission increases as alkylate petrol is used [14,15]. Therefore, it is unclear how the exhaust gas emission changes when alkylate petrol with different additives and regular petrol is used, which justifies further research in this particular area. The particular study points out that the fuels produced do not always fulfill the conditions as stated by the manufacturer, e.g. the reduction of engine exhaust gas. In case of two-stroke engines, there is a direct risk on human health. In addition, the study brings out that the removal of components that improve combustion from oil fuels might impair the combustion process and significantly increase the level of exhaust gas.

The current article aims at comparing the exhaust gas emission of a two-stroke engine when alkylate petrol and a blend of regular petrol and oil is used in a two-stroke engine, which is not equipped with a catalyst. The proportions of more significant dangerous compounds are brought out and results analyzed.

\section{Material and methods}

Over the course of study, engine tests were carried out on a two-stroke engine. Part-load tests were run on an engine and the exhaust gas emission measured, like in other similar tests [13,16]. Fractional distillation characteristics were carried out with test fuels as well as the test for assessing lubrication properties [12].

\begin{tabular}{ll}
\hline Name & Technical data \\
\hline Model & LTE145 \\
Type & 2 -stroke, air-cooled, one-cylinder \\
Piston stroke & $40 \mathrm{~mm}$ \\
Cylinder capacity & $63 \mathrm{~cm}^{3}$ \\
Maximum engine power & $2 \mathrm{hp}(1.5 \mathrm{~kW}) 3000 \mathrm{rpm}$ \\
Fuel & Unleaded petrol \\
Fuel to oil ratio of the fuel & $1 / 50$ \\
Ignition system & C.D.I \\
Spark plug type & F6RTC \\
\hline
\end{tabular}

Table 1. Technical data of the generator LTE145 
An increased friction in the engine might cause greater fuel consumption and faster wearing. An increase in the fuel consumption in turn conditions a greater exhaust gas emission. The technical data of the test device - a generator LTE145 equipped with a two-stroke engine - are given in Table 1.

A generator enables to test an engine at different loads while guaranteeing engine work stability. The engine was loaded at three different generator loads, which were $P_{G}=100,200$ and $300 \mathrm{~W}$, whereas the rotational speed of the engine crankshaft was $n_{e}=3000 \mathrm{rpm}$. During the tests, the exhaust gas emission of the engine was measured. At each engine mode, the exhaust gas emission was measured during $t=60 \mathrm{~s}$ after every second. Each test was repeated three times. The results indicate the average result of all three tests and standard deviation. The analyzer AVL SESAM-FTIR was used to measure the exhaust gas. The engine fuels used were special alkylate petrol for two-stroke engines and a blend of regular petrol E95 (A-class) and Addinol two-stroke engine oil MZ408 in a ratio of 1/50. The fuels were tested in a laboratory where their fractional distillation characteristics and density (device Automatic density meter DDM2910, standard EN ISO 12185) were determined and lubrication parameters assessed. The data of these results are given in Table 2 . The purpose of determining fractional distillation characteristics was to assess how big the proportion of lubrication oil in the fuel is since the proportion of lubrication oil in the fuel influences the exhaust gas emission of an engine. What is more, distillation characteristic was also necessary to assess the properties of fuels. The device Koehler K45090 was used for that objective. The device used for evaluating the lubrication parameters was GUNT TM 260. 03. To evaluate lubrication parameters, the force sufficient to overcome the force of friction between a steel pin and a steel disk was measured. The test device can be seen more closely on Figure 1 and test data in Table 3. During tests, the static and kinetic friction forces were determined. The measurements of the kinetic friction force were carried out on the rotational speeds of 20,50 and $70 \mathrm{rpm}$ of the steel disk.

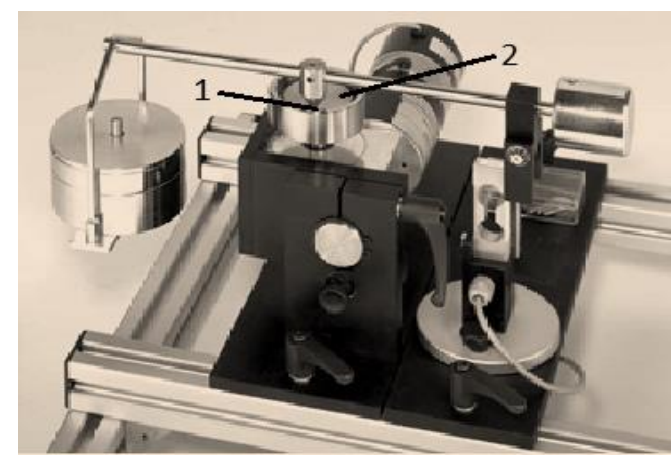

Fig. 1. Test device GUNT TM 260.03 for measuring friction force (1 - steel pin; 2 - steel disc) [17]

The lubrication parameters of the fuel impact the serviceable life and wearing of the engine. The technical condition of the engine is important for assuring low exhaust gas emission. When analyzing the test results, compounds that are widely known and most hazardous to human health, i.e. $\mathrm{CO}, \mathrm{CO}_{2}, \mathrm{NO}_{\mathrm{x}}, \mathrm{NO}_{2}, \mathrm{HC}$, and $\mathrm{C}_{4} \mathrm{H}_{6}$, were focused on [18;19]. At this point, 1,3-butadiene $\left(\mathrm{C}_{4} \mathrm{H}_{6}\right)$ is considered separately as it is a very dangerous compound to human health, which irritates mucous membranes, causes breathing problems, and is considered one of the factors predisposing leukemia $[5,19,20]$.

\section{Results and discussion}

The data of fuels' distillation are given in Table 2. The data indicate that alkylate petrol contains more volatile compounds for which reason the easier cold start of the engine and better evaporation of the fuel is guaranteed (see IBF, BP $10 \%$, E70). Parameters BP $50 \%$ and E100 describe the impact of fuel on the warming of an engine and smooth transition from one mode to another. Based on Table 2, it can be said that in case of alkylate petrol, $50 \%$ of the fuel distils on a lower temperature than regular petrol and oil blend (BP $50 \%$ ). What is more, in case of alkylate petrol, a bigger amount of fuel (E100) has distilled at $100^{\circ} \mathrm{C}$, which leads to the assumption that in case of alkylate petrol, the evaporation of the air-fuel mixture happens at lower temperatures, the engine warms more quickly and runs more stably. The evaporation of the air-fuel mixture in the engine cylinder can be described by parameters BP 90\% and E150. In case of cold outside temperature, it might happen that part of the air-fuel mixture remains unvaporized in the cylinder, which in turn increases the proportion of $\mathrm{CO}$ and $\mathrm{HC}$ in the exhaust gas. Based on Table 2 data concerning alkylate petrol, $90 \%$ of the fuel has distilled at a significantly lower temperature than the blend of regular petrol and oil. Therefore, it could be said that when alkylate petrol is used, the evaporation and combustion of the air-fuel mixture is more effective. Concerning the distillation residue, in case of alkylate petrol, the proportion of heavy fractions in the fuel is smaller, which leads to the conclusion that during combustion, the proportions of $\mathrm{CO}$ and $\mathrm{HC}$ decrease. The distillation residue characterizes the portion of non-vaporizing fuel and the proportion of oil in the fuel. The regular petrol standard EVS-EN 228:2012 determines a distillation residue of maximum $2 \%$ in A-class regular petrol. Therefore, it can be said that there is approximately $2 \%$ of lubrication oil in fuels. 


\begin{tabular}{lcc}
\hline Fractional distillation parameter & Petrol + Oil & Alkylate petrol \\
\hline Initial boiling point (IBP) & 38 & 28 \\
BP 10\% & 55 & 59 \\
BP 20\% & 60 & 64 \\
BP 30\% & 63 & 79 \\
BP 40\% & 87 & 93 \\
BP 50\% & 102 & 99 \\
BP 60\% & 118 & 103 \\
BP 70\% & 137 & 106 \\
BP 80\% & 158 & 109 \\
BP 90\% & 195 & 132 \\
E70 & 34 & 26 \\
E100 & 49 & 54 \\
E150 & 76 & 91 \\
Final boiling point (FBP) & 207 & 186 \\
Recovery wt \% & 95 & 95 \\
Residue wt \% & 4 & 3 \\
Loss wt $\%$ & 1 & 2 \\
Density $\left(15{ }^{\circ}\right.$ C), g/cm ${ }^{3}$ & 0.7918 & 0.7001 \\
\hline
\end{tabular}

Table 2. Fractional distillation parameters of test fuels

Table 3 contains data which characterize the lubrication properties of test fuels. With alkylate petrol, the static friction force is $28 \%$ higher. Results are similar regarding the kinetic friction force. Therefore, with alkylate petrol, as details start moving, the wearing of the engine is greater. The impact of fuel on the wearing of the details during the motion of work details is similar.

\begin{tabular}{ccc}
\hline Fuel & Petrol + Oil & Alkylate petrol \\
\hline $\begin{array}{c}\text { Static friction force, } \mathrm{N} \\
\text { Kinetic friction force } \\
(20 \mathrm{rpm}), \mathrm{N}\end{array}$ & 5.3 & 7.3 \\
$\begin{array}{c}\text { Kinetic friction force } \\
\quad(50 \mathrm{rpm}), \mathrm{N}\end{array}$ & 10.5 & 9.05 \\
$\begin{array}{c}\text { Kinetic friction force } \\
(70 \mathrm{rpm}), \mathrm{N}\end{array}$ & 9.3 & 8.8 \\
\hline
\end{tabular}

Table 3. The measurement data of the lubrication properties of test fuels

Based on data obtained during engine tests, it became evident that in case of the blend of regular petrol and oil, the proportion of hydrocarbons in the exhaust gas is higher at low loads of the engine (a load of $100 \mathrm{~W}$ ) (see Fig. 2). As the load increases, the proportion of hydrocarbons decreases. However, with alkylate petrol, the proportion of hydrocarbons in the exhaust gas is the smallest at $200 \mathrm{~W}$ load. As the load increases (300 W), the proportion of hydrocarbons also starts to increase. In comparison to the data obtained during the use of the blend of regular petrol and oil, at heavy engine load, the proportion of hydrocarbons in the exhaust gas is $\sim 18 \%$ higher with alkylate petrol. The decrease in the proportion of hydrocarbons is connected to the rise in the combustion and engine temperatures as the load increases. With alkylate petrol at heavy engine load, the increase in the proportion of hydrocarbons is conditioned by the combustion of oil added to the fuel. As the proportion of air-fuel mixture in the cylinder increases, the entire air-fuel mixture does not evaporate and burn completely (heavy fractions in particular), for which reason the amount of hydrocarbons increases. In addition, the partial removal of benzene from the fuel might cause the inefficient combustion of the air-fuel mixture, especially at heavy engine loads where fuel is directed into the engine significantly more than at low engine loads. 


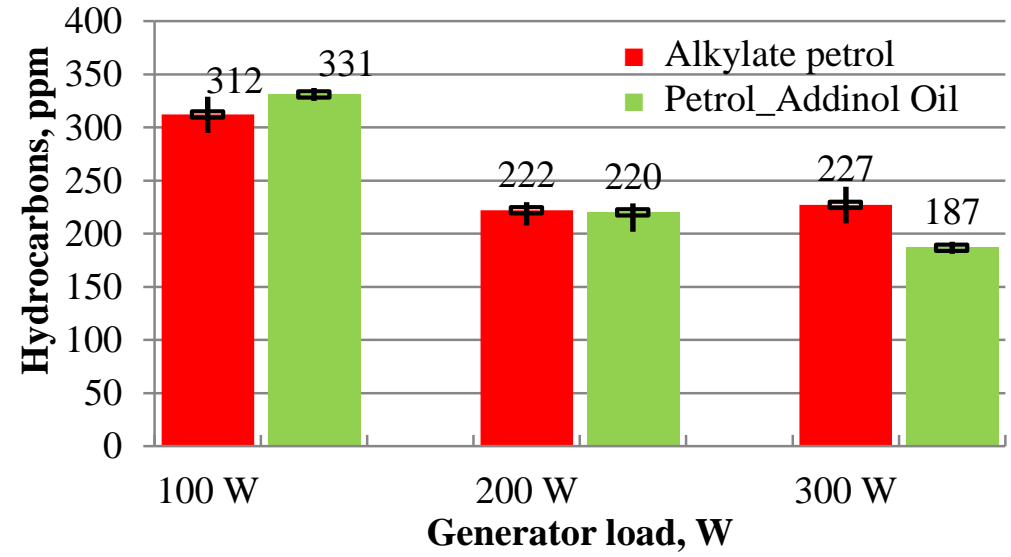

Fig. 2. The proportion of hydrocarbons in the exhaust gas

Figure 2 demonstrates that when alkylate petrol is used, the proportion of carbon monoxide is $\sim 60 \%$ higher at all engine loads. This could also be due to the combustion of oil added to the fuel as well as the removed benzene, which causes the combustion quality of the air-fuel mixture to drop. Both fuels demonstrate a tendency of having the lowest $\mathrm{CO}$ level at the load of $200 \mathrm{~W}$. In this particular case, it is caused by the constructional peculiarity of the engine as the airfuel mixture is kept rich at heavy engine load to ensure a lower temperature in the combustion process. In case of a rich air-fuel mixture, the proportion of $\mathrm{CO}$ in the exhaust gas increases.

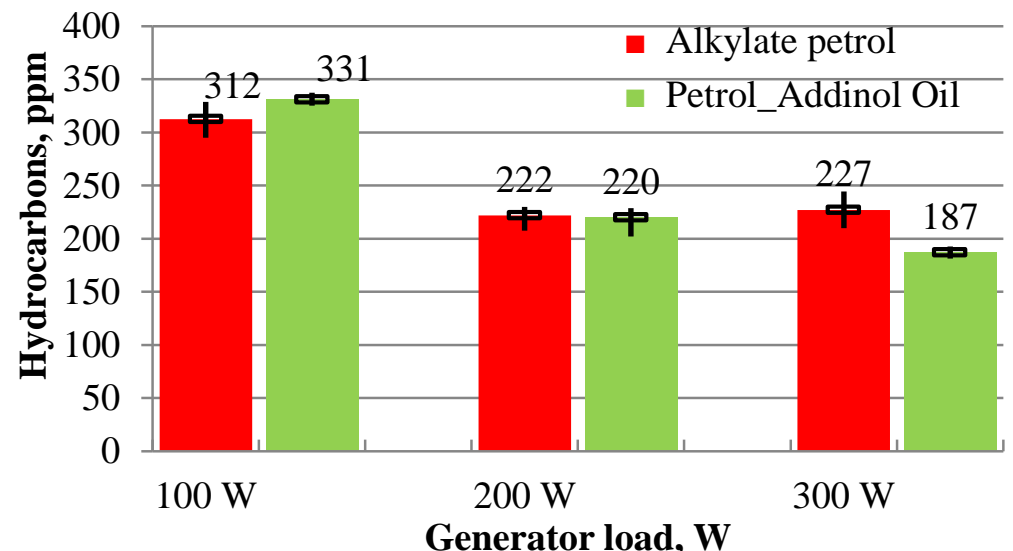

Fig. 3. The proportion of carbon monoxide in the exhaust gas

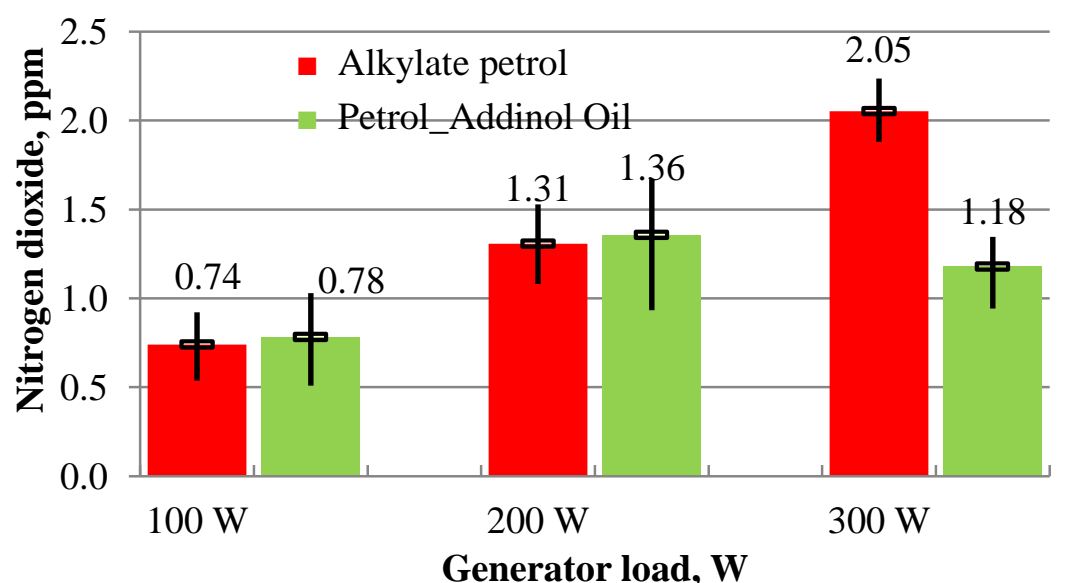

Fig. 4. The proportion of nitrogen dioxide in the exhaust gas

With nitrogen dioxide (see Fig. 4), it becomes clear that when alkylate petrol is used, the proportion of nitrogen dioxide in the exhaust gas increases as the engine load increases. With the blend of regular petrol and oil, the proportion 
of nitrogen dioxide in the exhaust gas decreases at heavy engine loads (when comparing the proportions of nitrogen dioxide at engine loads of $200 \mathrm{~W}$ and $300 \mathrm{~W}$ ). Compared to alkylate petrol, the proportion of nitrogen dioxide at heavy engine loads has decreased $\sim 42 \%$. At low engine loads ( $100 \mathrm{~W}$ and $200 \mathrm{~W}$ ) with alkylate petrol, the proportion of nitrogen dioxide decreases $\sim 4 \%$.

When looking at the entire proportion of nitrogen compounds (NOx) coming into existence during the combustion of fuel (Figure 5), it can be seen that when alkylate petrol is used at low engine loads (100 W and $200 \mathrm{~W}$ ), the proportion of nitrogen compounds does not change significantly. Compared to the blend of regular petrol and oil at engine load of $100 \mathrm{~W}$, the proportion of nitrogen compounds is 57\% lower with alkylate petrol. At engine load of $200 \mathrm{~W}$, the proportion of nitrogen compounds is $44 \%$ lower. At heavy engine load $(300 \mathrm{~W})$ with alkylate petrol, the proportion of nitrogen compounds is $7 \%$ higher in comparison to the use of regular petrol and oil blend. In contrast to alkylate petrol, when the blend of oil and regular petrol is used, the proportion of nitrogen compounds in the exhaust gas decreases as the engine load increases. Based on Figure 3, it can be deduced that the combustion temperature of alkylate petrol is low, and thus, the entire air-fuel mixture does not burn completely. For this reason, the proportion of nitrogen compounds in the exhaust gas is low and the proportion of CO high. The results are opposite when the blend of regular petrol and oil is used. The decrease in the proportion of nitrogen compounds as the engine load increases is conditioned by the use of richer air-fuel mixture during the increase in the engine load.

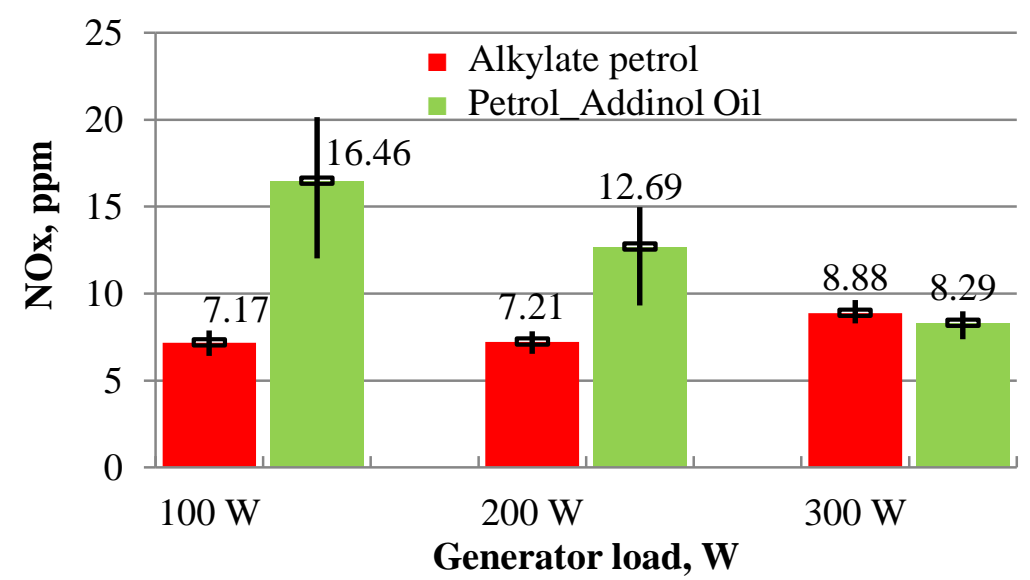

Fig. 5. The proportion of nitrogen compounds in the exhaust gas

The proportion of carbon dioxide in the exhaust gas with either fuel decreases as the engine load increases (see Figure 6). With alkylate petrol, the proportion of carbon dioxide is lower at all engine loads than with regular petrol and oil blend. An interesting nuance is that when the blend of regular petrol and oil is used, the increase in engine load brings about a greater decrease in the proportion of carbon dioxide than with alkylate petrol. A lower level of carbon dioxide in the exhaust gas with alkylate petrol is conditioned by the high level of carbon monoxide.

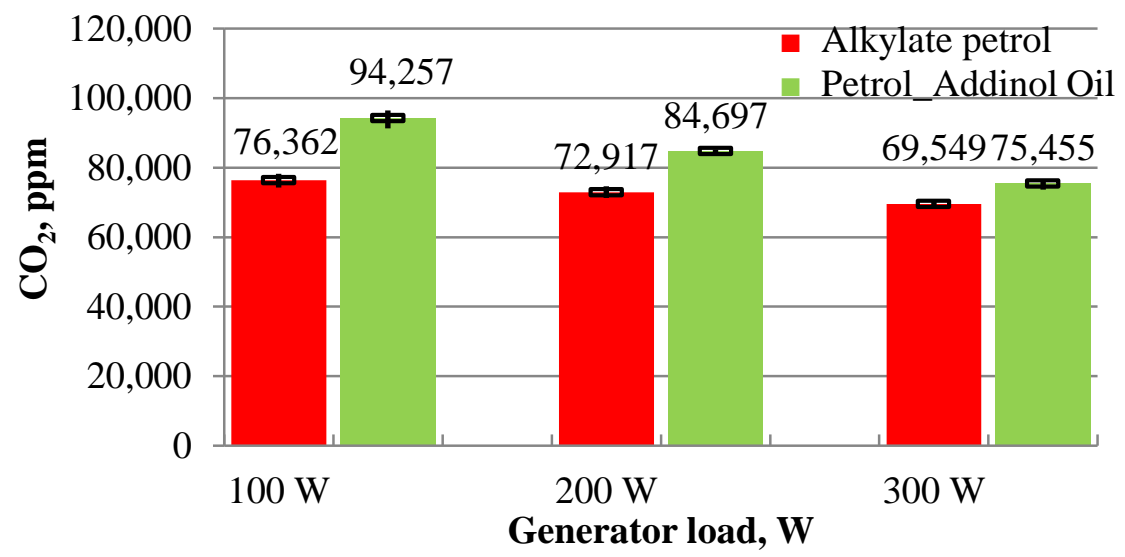

Fig. 6. The proportion of carbon dioxide in the exhaust gas

As the engine load increases, the proportion of 1,3-butadiene in the exhaust gas decreases with the use of regular petrol and oil blend. With alkylate petrol, the proportion of 1,3-butadiene decreases at engine loads of $100 \mathrm{~W}$ and $200 \mathrm{~W}$. At the engine load of $300 \mathrm{~W}$, the proportion of it in the exhaust gas starts to increase. At low engine loads during the use of alkylate petrol, the proportion of 1,3-butadiene is $\sim 36 \%$ lower. At heavy engine load, the proportion of 1,3-butadiene with either fuel is similar. 


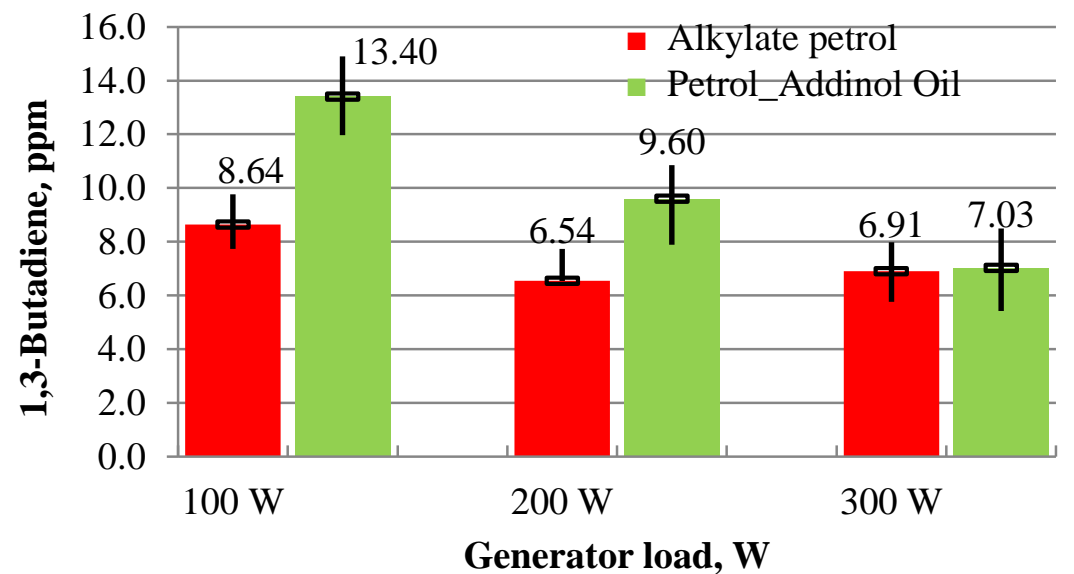

Fig. 7. The proportion of 1,3-butadiene in the exhaust gas

The above given data indicate that when alkylate petrol is used in a two-stroke engine, the proportions of several dangerous compounds (mostly $\mathrm{CO}$ and $\mathrm{HC}$ ) in the exhaust gas increase. The main advantage of using the blend of regular petrol and oil appears at heavy engine loads when, according to the results, the proportion of, for example, CO in the exhaust gas was significantly lower when compared to the use of alkylate petrol. Therefore, this particular study partly confirms the results in Magnusson et al. 2000 and Magnusson et al. 2002, which state that the engine exhaust gas emissions increase when alkylate petrol is used [14,15].

\section{Conclusions}

In conclusion, it can be said that based on the distillation data, the properties of alkylate petrol for use in an engine are better than those of the blend of regular petrol and oil. During the measurement of friction force in order to assess the lubrication properties of fuels, it became evident that the kinetic friction force was similar with both fuels. The static fiction force, which causes greater fuel consumption and wearing of the engine, was $28 \%$ higher with alkylate petrol than in case of regular petrol and oil blend. An increase in the fuel consumption also conditions greater exhaust gas emission.

The proportions of $\mathrm{CO}$ and $\mathrm{HC}$ either increase or remain the same when alkylate petrol is used at all engine loads. The test results indicated that at low engine loads, it would be efficient to use alkylate petrol, however, at heavy engine loads, it would be more rational to use the blend of regular petrol and oil. In comparison to the blend, some airfuel mixture remains unburned, which can be inferred from the significantly higher $\mathrm{CO}$ level in the exhaust gas when alkylate petrol is used. What is more, the proportion of nitrogen compounds decreases when alkylate petrol is used. This could be due to the benzene having been removed from the alkylate petrol that causes the inefficient combustion of the air-fuel mixture. This becomes most evident at heavy engine load. When hand tools are used, it is important to note the type of engine the tool is equipped with. With continuous mode engines, the use of regular petrol and oil blend would be more practical. With variable mode engine, it would be more effective to use alkylate petrol. The tests of this study did not confirm that the proportion of dangerous compounds in the exhaust gas change significantly when alkylate petrol is used in a two-stroke engine.

In addition, the study reveals that the use of oil fuels in two-stroke engines does not enable a significant reduction of exhaust gas emission. Therefore, in the future, it is relevant to develop a standard for two-stroke engine fuels to avoid an increased risk on human health by the use of special fuels. What is more, the study serves as a basis for developing biofuels (e.g. bioethanol fuel) for a two-stroke engine. Modelling engine's combustion process is important for the more efficient use of alkylate petrol. Furthermore, it is crucial to study how alkylate petrol impacts the thermal process and waste heat of the engine, which could be used for the more convenient use of hand tools $[21,22]$.

\section{References}

[1] Rice, S. A., Valley, G. 2004. Human healt risk assessment of CO2: Survivors of acute high-level exposure and populations sensitiive to prolonged low-level exposure. Third annual conference on karbon sequestration, Alexandria, Virginia, USA.

[2] Arapatsakos, C., Dimitriadis, T., Yaseli DE La Parra, E. M. 2013. The gas emissions influence from the use of different mixing oils in a two stroke engine. Recent Advances in Environmental Science, Energy, Enviromental and Structural Engineering Series 7, pp $177-181$.

[3] Fridell, E. Haeger-Eugensson, M., Moldanova, J., Forsberg, B., Sjöberg, K. 2014. A modelling study of the impact on air quality and health due to the emissions from E85 and petrol fuelled cars in Sweden. Atmospheric Environment, Volume 82, pp 1-8. 
[4] Coburn, T.C., Kelly, K.J., Bailey, B.K. 2011. Reduction in Vehicle Emissions Attributable to Alternative Transportation Fuels and Its Prospective Impact on Air Quality and Public Health. Applied Occupational and Environmental Hygiene, pp 395 - 405.

[5] Winebrake, J., Wang, M., He, D. 2011. Toxic emissions from mobile sources: A Total fuel cycle analysis for conventional and alternative fuel vehicles. Journal of the Air \& Waste Management Association. 51, pp 1073-1086.

[6] Ritslaid, K.; Küüt, A.; Olt, J. (2010). State of the Art in Bioethanol Production. Agronomy Research, 8(1), 236 254.

[7] Küüt, A., Ilves, R., Vlasov, A., Soots, K., Olt, J. (2014). Impact of bioethanol fuel on the output parameters of a two-stroke reciprocating engine. Engineering for Rural Development, Jelgava, 29.-30.05.2014. Latvia University of Agriculture, 288 - 295.

[8] Hönig, V.; Kotek, M; Marik, J. (2014). Use of butanol as a fuel for internal combustion engines. Agronomy Research, 12(2), 333 - 340.

[9] Seggiani, M., Prati, M.V., Costagiola, M.A., Puccini, M., Vitolo, S. 2012. Bioethanol-gasoline fuel blends: Exhaust emissions and morphological characterization of particulate from a moped engine. Journal of the Air \& Waste Management Association. 62, pp 888-897.

[10] Irimescu, A.; Ionel, I.; Dungan, L. I. \& Cioabla, A. E. (2010). Initial Theoretical Study for a Heavy Duty Diesel Engine Conversion to Biogas Fuelling, Annals of DAAAM for 2010 \& Proceedings of the 21st International DAAAM Symposium, 20-23rd October 2010, Zadar, Croatia, ISSN 1726-9679, ISBN 978-3-901509-73-5, Katalinic, B. (Ed.), pp. 0999-1000, Published by DAAAM International Vienna, Vienna.

[11] Moroianu, C. \& Patrichi, I. (2010). The Combustion Oscillograms of Water /Heavy Fuel Emulsion Droplet, Annals of DAAAM for 2010 \& Proceedings of the 21st International DAAAM Symposium, 20-23rd October 2010, Zadar, Croatia, ISSN 1726-9679, ISBN 978-3-901509-73-5, Katalinic, B. (Ed.), pp. 0455-0456, Published by DAAAM International Vienna, Vienna

[12] Zardini, A. A., Platt, S. M., Clairotte, M., Haddad, I.E., Temime-Roussel, B., Marchand, N., Ježek, I., Drinovec, L., Močnik, G., Slowik, J. G., Manfredi, U., Prévôt, A. S.H., Baltensperger, U., Astorga, C. 2014. Effects of alkylate fuel on exhaust emissions and secondary aerosol formation of a 2-stroke and a 4-stroke scooter. Atmospheric Environment, Volume 94, pp. 307-315.

[13] Alander, T., Antikainen, E., Raunemaa, T., Elonen, E., Rautiola, A., Torkkell K. 2005. Particle Emissions from a Small Two-Stroke Engine:Effects of Fuel, Lubricating Oil, and Exhaust Aftertreatment on Particle Characteristics. Aerosol Science and Technology, pp. 151-161.

[14] Magnusson, R., Nilsson, C., and Andersson, B. (2002). Emission of Aldehydes and Ketones from a Two-Stroke Engine Using Ethanol and Ethanol-Blended Gasoline as a Fuel, Environ. Sci. Technol, pp.1656-1664.

[15] Magnusson, R., Nilsson, C., Andersson, K., Andersson, B., Gieling, R.,Wiberg, K., Ostman, C., and Rannug, U. (2000). Determination of Chemical Composition and Mutagenicity in Particles from Chainsaw Exhaust. Experimental Set-up, Stability and Results from Two Different Fuels, Environ. Technol, pp. 819-829.

[16] Singh, A.K. 2011. Castor oil-based lubricant reduces smoke emission in two-stroke engines. Industrial Crops and Products, Volume 33, Issue 2, pp 287-295.

[17] GUNT Hamburg. Available from:http://www.mutiaranata.com/product/detail/tm-260-03-experimental-modulepin-on-disc (15.11.2013)

[18] Graham, L. A., Belisle, S. L., Baas, C. 2008. Emissions from light duty gasoline vehicles operating on low blend ethanol gasoline and E85. Atmospheric Environment 42, pp 4498-4516.

[19] Kirman, C.R., Grant, R.L. 2012. Quantitative human health risk assessment for 1,3-butadiene based upon ovarian effects in rodents. Regulatory Toxicology and Pharmacology, Volume 62, Issue 2, pp 371-384.

[20] EPA. United States Enviromental Protection Agency. http://www.epa.gov/airtoxics/hlthef/butadien.html\#ref1. (10.01.2015).

[21] Olt, J., Mikita, V., Roots, J., Jasinskas, J. (2015) Cylinder Pressure Characteristics of Turbocharged and Naturally Aspirated Diesel Engines. Annals of DAAAM for 2014 \& Proceedings of the 25st International DAAAM Symposium. Procedia Engineering 100, pp. 350-359.

[22] Apostol, V., Pop, H., Dobrovicescu, A., Prisecaru, T., Alexandru, A., Prisecaru, M. (2015) Thermodynamic Analysis of ORC Configurations Used for WHR from a Turbocharged diesel engine. Annals of DAAAM for 2014 \& Proceedings of the 25st International DAAAM Symposium. Procedia Engineering 100, pp. 549-558. 